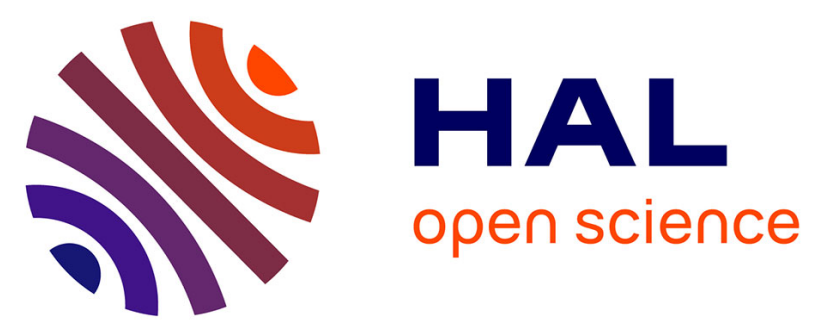

\title{
Relationships between botanical composition, yield and forage quality of permanent grasslands over the first growth cycle
}

Donato Andueza, Augusto Rodrigues, Fabienne Picard, Nicolas Rossignol, René Baumont, U. Cecato, Anne A. Farruggia

\section{To cite this version:}

Donato Andueza, Augusto Rodrigues, Fabienne Picard, Nicolas Rossignol, René Baumont, et al.. Relationships between botanical composition, yield and forage quality of permanent grasslands over the first growth cycle. Grass and Forage Science, 2016, 71, pp.366-378. 10.1111/gfs.12189 . hal02640877

\section{HAL Id: hal-02640877 \\ https: / hal.inrae.fr/hal-02640877}

Submitted on 28 May 2020

HAL is a multi-disciplinary open access archive for the deposit and dissemination of scientific research documents, whether they are published or not. The documents may come from teaching and research institutions in France or abroad, or from public or private research centers.
L'archive ouverte pluridisciplinaire HAL, est destinée au dépôt et à la diffusion de documents scientifiques de niveau recherche, publiés ou non, émanant des établissements d'enseignement et de recherche français ou étrangers, des laboratoires publics ou privés.

\section{다(1)(2)}

Distributed under a Creative Commons Attribution - ShareAlikel 4.0 International 


\title{
Relationships between botanical composition, yield and forage quality of permanent grasslands over the first growth cycle
}

\author{
D. Andueza*,†, A. M. Rodrigues*,†, $\ddagger$ F. Picard*,†, N. Rossignol*,†, R. Baumont*,†, \\ U. Cecato $\ddagger$ and A. Farruggia* $\dagger$ \\ *INRA, UMRI 213 Herbivores, Saint-Genès-Champanelle, France, †Clermont Université, VetAgro Sup, UMR \\ Herbivores, Clermont-Ferrand, France, łUniversidade Estadual de Maringá, Maringá, PR, Brazil
}

\begin{abstract}
This study examined the relationships between botanical composition and forage parameters (yield and forage quality variables) in 153 permanent grasslands located in the Massif Central of France. Grasslands were sampled at two vegetation stages in the first growth cycle. Botanical composition, yield, ash, crude protein, neutral detergent fibre, acid detergent fibre, acid detergent lignin, organic matter digestibility (OMD) and voluntary intake (VI) were estimated for each sample. Temporal variability in species-forage parameter relationships were accounted for using innovative multivariate analyses applied mainly in ecological science. Crude protein and OMD were weakly correlated when each harvest time was analysed separately. Species-forage parameter relationships remained stable during the first growth cycle. The stability of these relationships indicates that permanent grasslands dominated by competitive species were associated with high yield and forage quality values whereas permanent grasslands composed of conservative species and/or high proportions of senescent material were associated with high structural carbohydrate values and low yield, OMD and VI values. Based on these relationships, we propose a typology of permanent grasslands along with a set of indicator species enabling non-specialist botanists to easily classify grasslands for grassland management purposes.
\end{abstract}

Keywords: floristic composition, chemical composition, organic matter digestibility, voluntary intake, permanent grasslands

Correspondence to: D. Andueza, INRA, UMR1213 Herbivores, F-63122 Saint-Genès Champanelle, France.

E-mail: donato.andueza@clermont.inra.fr

Received 10 June 2014; revised 2 October 2014

\section{Introduction}

The EC definition of permanent grassland is a plot 'that has not been included in the crop rotation of the holding for five years or longer', yet European permanent grassland is usually kept for longer than five years and is not sown, although, in some cases, it may be oversown or resown depending on management intensity. Permanent pastures, as part of permanent grasslands are used to feed livestock and are typically composed of a mixture of native self-seeded grasses and forbs. These botanical communities are maintained by agricultural practices (livestock grazing and/ or mowing) but are not substantially modified by intensive inorganic fertilization, drainage or herbicide use (Reheul et al., 2007). They are also called unimproved permanent grasslands, but if one or more of these practices is used on them, they are reclassed as semi-improved or improved permanent grasslands according to degree of use.

Permanent grasslands are a major feature of land use in Europe, covering more than a third of the European agricultural area (FAO, 2008). Forage from permanent grasslands is a key component of ruminant diets and also plays a key role in differentiating products derived from livestock fed with this type of forage (Martin et al., 2005).

The feed value of the main forage grass species found in temporary grasslands is well established (Baumont et al., 2007), but there is a lack of adequate estimates of the feed value of forage obtained from permanent grasslands (Bruinenberg et al., 2002; Pelve et al., 2012). The large diversity of indigenous grasses and dicotyledons in permanent grasslands and their broad variability in phenology and competitiveness (Rossignol et al., 2014) may explain the difficulty in obtaining good estimates of nutritive value. Seasonal changes in plant abundances further complicate efforts to predict forage quality. Indeed, Todorova and Kirilov 
(2002) reported huge variation (19-69\% of total yield) in the proportion of Agrostis capillaris in different periods of the first growth cycle of an Ag. capillaris-Festuca fallax grassland. Likewise, Andueza et al. (2013) reported important variations in the floristic composition of two botanically different extensively managed permanent grasslands studied at three dates during the first growth cycle in the Massif Central of France. This complexity is the reason why the variability in the feed value of permanent grasslands, and its evolution over the first growth cycle, are still poorly understood.

This study set out to (i) describe the relationship between the botanical composition of permanent grasslands (seminatural unimproved and semiimproved pastures and also grasslands improved in the past but unploughed for at least 5 years) and forage parameters:, i.e., yield, chemical composition and feed value, (ii) determine the stability of this relationship over the first growth cycle and (iii) characterize permanent grasslands on the basis of these variables. These objectives were achieved using innovative multivariate analyses that take into account how the relationship changes over time.

\section{Materials and methods}

\section{Grasslands and sampling}

A total of 153 permanent grasslands over 5 years old with no history of ploughing were randomly selected from locations in the Auvergne region of central France. The sampled grasslands were representative of different types of soil [granitic $(n=78)$ and volcanic $(n=75)$ ], altitude [ranging from 300 to $1350 \mathrm{~m}$ a.s.l. ( $n=83$ for altitude $>900 \mathrm{~m}$ a.s.l., $n=70$ for an altitude $<900 \mathrm{~m}$ a.s.l.)] and annual rainfall [ranging from 480 to $1440 \mathrm{~mm}(n=23$ for an annual rainfall $>1000 \mathrm{~mm}, \quad n=130$ for an annual rainfall $<1000 \mathrm{~mm}$ )]. Plots included grasslands dominated by Lolium perenne or Dactylis glomerata but also Holcus lanatus, Festuca rubra or Ag. capillaris. The mean \pm s.d. soil chemical and physical properties of the studied area according to Hulin et al. (2011) were as follows: $45 \pm 14 \%$ sand, $34 \pm 10 \%$ loam, $21 \pm 8 \%$ clay, $7 \cdot 2 \pm 5.6 \%$ organic matter, $5.9 \pm 0.34 \mathrm{pH}$, $280 \pm 73 \mathrm{mg}$ per kg Olsen-P status, $350 \pm 200 \mathrm{mg}$ per $\mathrm{kg} \mathrm{K}$ status and $22.7 \pm 10.39$ CEC. Each grassland was sampled twice in 2005 during the first cycle of growth: once when farmers made silage (Silage stage, SS), that is, around the heading stage of dominant grass species, and once when they made hay (Hay stage, HS), that is, around the flowering stage of dominant grass species. In each grassland, we used different plots for SS and HS samples. Sampling was performed on surfaces left uncut by farmers when they decided to harvest the grasslands between the two sampling periods. On average, HS sampling came three weeks after the SS sampling. For each sampling, five randomized $0.25 \mathrm{~m}^{2}$ subplots $(0.5 \times 0.5 \mathrm{~m})$ were cut within each grassland at $5 \mathrm{~cm}$ above ground level using a small lawnmower. Forage obtained in the five subplots was pooled to give a single representative sample per grassland, then weighed and divided into two subsamples. The first subsample (125 g fresh material) was stored at $-20^{\circ} \mathrm{C}$ and used to characterize botanical composition. The second subsample was dried at $60^{\circ} \mathrm{C}$ for $72 \mathrm{~h}$ to assess dry-matter (DM) content, then ground in a hammer mill through a $0 \cdot 8$-mm screen.

\section{Determination of botanical composition}

First, each sample was sorted into fresh forage and senescent material (Sm). Botanical composition of fresh forage was then determined by hand-sorting the samples into plant species. Species identification and nomenclature followed Flora Europea (Tutin et al., 1964-1980). Individual species and Sm were then dried at $60^{\circ} \mathrm{C}$ for $72 \mathrm{~h}$ and weighed. Proportion of each species and Sm was expressed as species and Sm contribution to total yield.

\section{Determination of chemical composition and feed value}

Ash and crude protein (CP) contents, in vivo organic matter digestibility (OMD) and voluntary intake (VI) by sheep were estimated by near-infrared reflectance spectroscopy (NIRS) according to the global model proposed by Andueza et al. (2011). Specific NIRS models were also built for the estimations of neutral detergent fibre (NDF), acid detergent fibre (ADF) and acid detergent lignin (ADL) contents. The reference methods used were proposed by Van Soest et al. (1991) for NDF and Van Soest and Robertson (1980) for ADF and ADL and performed on an Ankom analyzer (Ankom ${ }^{\circledR}$ Tech. Co., Fairport, NY, USA). For all determinations, before running the NIRS predictions, we first calculated Mahalanobis distance $(\mathrm{H})$ between the spectra of each sample and the average calibration spectra to check the calibration models were compatible with the samples to be predicted. No samples were discarded $(\mathrm{H}>3)$. Predicted values for chemical composition, OMD and VI of samples were within the range of values of the databases used to develop the calibration equations. Standard errors of cross-validation were $14 \cdot 0,12 \cdot 1$ and $6.0 \mathrm{~g} \mathrm{~kg}$ $\mathrm{DM}^{-1}$, and coefficients of determination of cross-validation were 0.96, 0.94 and 0.90 for NDF, ADF and ADL respectively. Ash content, $\mathrm{CP}, \mathrm{VI}, \mathrm{OMD}, \mathrm{NDF}, \mathrm{ADF}$ and ADL were included in the analysis together with yield as variables representing forage quality. 


\section{Data analysis}

Differences between sampling periods for forage parameter determinations were tested by Anova. The species proportions and forage parameters for each grassland and period of sampling generated two sequences of tables: one sequence of two tables for the species proportions at both SS and HS sampling periods and another sequence of two tables for the eight forage parameters, again at both the SS and HS sampling periods (Figure 1). The common relationship between botanical composition and forage parameters of permanent grassland and the stability of this relationship over both sampling periods were investigated using STATICO, a special kind of multivariate analysis (Simier et al., 1999; Thioulouse et al., 2004).

STATICO is a three-step method in which each table is first analysed separately by principal component analysis. The relationship between species and forage parameter is assessed for each period using a co-inertia analysis on each species-forage parameter pair of tables (Doledec and Chessel, 1994). Finally, a partial triadic analysis (Thioulouse and Chessel, 1987) is run on the sequence of cross-tables produced by the co-inertia analyses to assess the relationships that are stable along the sequence of cross-tables, that is over the two sampling periods here. The main outputs of

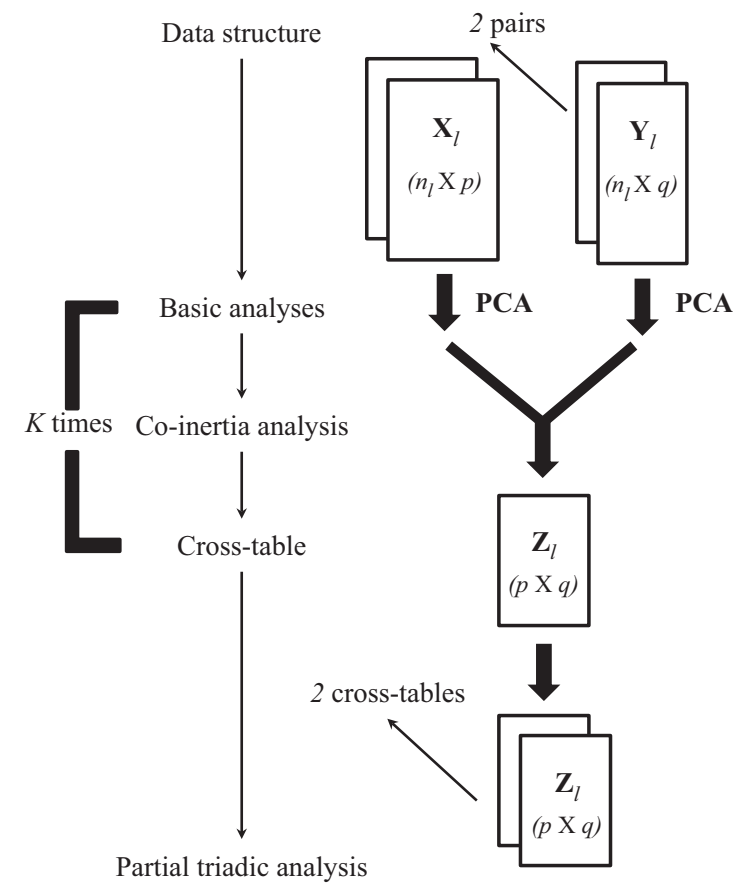

Figure I STATICO flow chart (adapted from Thioulouse et al., 2004). this analysis are the interstructure, compromise and intrastructure. The compromise gives a picture of the common relationship between floristic composition and forage parameters over the two periods. The interstructure gives the importance of each period in the construction of the compromise, while the typological value gives an idea of how much the compromise expresses the information from each period. The intrastructure (trajectories) summarizes the variability of the species-forage parameters relationships around the common structure defined by the compromise between the two sampling periods (Thioulouse et al., 2004; Thioulouse, 2011).

Before implementing the STATICO analysis, botanical composition data were Hellinger-transformed to factor out double absence of species being considered a resemblance between sites (Legendre and Gallagher, 2001), and forage parameter data were standardized (divided by the variance). For each sampling period, the significance of the relationship between botanical composition and forage parameter tables revealed by the coinertia analyses was tested using a Monte Carlo test. Then, a grassland classification scheme was constructed using a hierarchical cluster analysis based on the row coordinates in the forage parameters space of a co-inertia analysis (Dray et al., 2003) performed between botanical composition and forage parameters of the SSperiod sampling. This method classifies swards by maximizing intragroup homogeneity and intergroup diversity. The number of groups was proposed by the scree test (Cattell, 1966). Multivariate analyses were carried out with GNU-project R software version R 2.13.2 (R Foundation for Statistical Computing, http://www.Rproject.org) using the ADE4 package (Thioulouse et al., 1997). Finally, the effect of these groups on the variables related to botanical composition and forage parameters was tested by ANova. The model included group and sampling period as fixed effects and grassland as random effect. Period of sampling was considered as a repeated measure. Arcsine square root transformation was performed on percentage species before statistical analysis to improve normality and homoscedasticity (Sokal and Rohlf, 1981). ANovas were performed using SAS statistical software (SAS, 2000).

\section{Results}

\section{Yield, forage quality and species diversity}

Yield and forage quality characteristics for both harvesting periods of the sampled grasslands are reported in Table 1. Estimated values for ash content, CP content, OMD and VI showed higher average values at SS than at HS, whereas average values for yield, NDF, $\mathrm{ADF}$ and ADL were higher at HS than at SS. 
Table I Mean, standard deviation (s.d.), minimum (min) and maximum (max) values obtained for yield and NIRS-estimated values for ash, crude protein (CP), neutral detergent fibre (NDF), acid detergent fibre (ADF), acid detergent lignin (ADL), organic matter digestibility (OMD) and voluntary intake (VI) of permanent grasslands sampled at two sampling periods (sp): silage stage (SS) and hay stage (HS).

\begin{tabular}{|c|c|c|c|c|c|c|c|c|c|c|}
\hline & \multicolumn{4}{|c|}{ SS } & \multicolumn{4}{|c|}{ HS } & \multirow[b]{2}{*}{ s.e. } & \multirow[b]{2}{*}{ sp } \\
\hline & Mean & s.d. & Min & Max & Mean & s.d. & Min & Max & & \\
\hline Yield (t DM ha ${ }^{-1}$ ) & $4 \cdot 22$ & $2 \cdot 45$ & 0.37 & $9 \cdot 39$ & $5 \cdot 42$ & $2 \cdot 81$ & 0.49 & $10 \cdot 69$ & $0 \cdot 21$ & $* * *$ \\
\hline Ash $\left(\mathrm{g} \mathrm{kg} \mathrm{DM}^{-1}\right)$ & 84 & $12 \cdot 0$ & 61 & 124 & 75 & $10 \cdot 1$ & 58 & 103 & $0 \cdot 89$ & $* * *$ \\
\hline $\mathrm{CP}\left(\mathrm{g} \mathrm{kg} \mathrm{DM}^{-1}\right)$ & 114 & $27 \cdot 0$ & 67 & 200 & 84 & $20 \cdot 0$ & 47 & 168 & $1 \cdot 92$ & $* * *$ \\
\hline $\mathrm{NDF}\left(\mathrm{g} \mathrm{kg} \mathrm{DM}^{-1}\right)$ & 560 & $44 \cdot 0$ & 428 & 717 & 607 & $31 \cdot 6$ & 477 & 685 & $3 \cdot 09$ & $* * *$ \\
\hline $\operatorname{ADF}\left(\mathrm{g} \mathrm{kg} \mathrm{DM}^{-1}\right)$ & 296 & $29 \cdot 7$ & 221 & 466 & 328 & $19 \cdot 2$ & 272 & 376 & $2 \cdot 02$ & $* * *$ \\
\hline $\mathrm{ADL}\left(\mathrm{g} \mathrm{kg} \mathrm{DM}^{-1}\right)$ & 41 & 14 & 12 & 89 & 46 & $8 \cdot 2$ & 28 & 79 & $0 \cdot 91$ & $* * *$ \\
\hline $\mathrm{OMD}\left(\mathrm{g} \mathrm{g}^{-1}\right)$ & 0.71 & 0.06 & 0.52 & 0.79 & 0.62 & $0 \cdot 04$ & 0.50 & 0.74 & $0 \cdot 00$ & $* * *$ \\
\hline VI (g per kg BW ${ }^{0.75}$ ) & $69 \cdot 4$ & $7 \cdot 13$ & $51 \cdot 2$ & $83 \cdot 8$ & $64 \cdot 4$ & $6 \cdot 43$ & $47 \cdot 9$ & $79 \cdot 3$ & $5 \cdot 49$ & $* * *$ \\
\hline
\end{tabular}

s.e., Standard error; $* * * P<0.001$.

In total, 125 different plant species (Table 2) were identified in the 306 samples (153 plots * 2 sampling periods), including thirty-six species of grasses (between 3 and 15 species per sample), seventy-eight species of forbs (0-23 species per sample) and eleven species of legumes (0-5 species per sample). Proportion of grasses ranged from 5 to $99 \%$ at SS and from 12 to $97 \%$ at HS. Proportion of forbs ranged from 0 to $66 \%$ at both SS and HS. Proportion of legumes ranged from 0 to $55 \%$ at SS and from 0 to $47 \%$ at HS. Proportion of Sm ranged from 0 to $81 \%$ at SS and from 0 to $47 \%$ at HS.

\section{Relationship between botanical composition and forage parameters}

Co-inertia analyses showed a significant correlation $(P<0.001)$ between botanical composition and forage parameter for each sampling period, allowing us to implement the STATICO analysis.

\section{Interstructure and typological values}

The interstructure factor map (Figure 2a) allows an examination of how the relationships between species and forage parameters change according to the two different periods. The eigenvalue of the first axis $(81 \%$ of overall inertia) clearly prevailed over the eigenvalue of the second axis (19\% of overall inertia). The arrows on the interstructure factor map (Figure 2a) pointed in the same direction on the first axis which showed that the costructure between forage parameters and botanical composition of permanent grasslands was similar throughout the SS and HS periods. The data from both sampling periods thus had the same influence on the compromise. However, the typological value showed that the compromises better expressed the information contained in tables derived from the SS sampling period $\left(\cos ^{2}=0.95\right)$ than from the HS sampling period $\left(\cos ^{2}=0 \cdot 82\right)$.

\section{Compromise}

The compromise expressed the relationship between species and forage parameters over the two periods. The projection of variables (species and forage parameters) on the first two axes of the compromise enabled us to spot associations among species (Figure 2c) and among forage parameters (Figure 2b). Furthermore, comparing the coordinates of the species and forage parameters on the first two axes of the compromise enabled us to highlight which of the species were related to forage-quality variables and yield. In this sense, the first axis was dominant, accounting for $72 \%$ of overall inertia, whereas the second axis accounted for just $11 \%$ of inertia. Looking at the factor map of forage parameters (Figure 2b), the first axis displayed an opposition between estimated NDF, ADF and ADL values on one side and estimated OMD, VI and yield of permanent grassland on the other, thus expressing a gradient of forage quantity and quality. The second axis was characterized by an estimated CP value gradient. Ash content was closely correlated with $\mathrm{CP}$ content. In Figure 2c, species were ranked according to their proportion in permanent grasslands. Running a comparison of both compromise figures allowed us to characterize permanent grasslands according to the relationship between forage parameters and characteristic species. Thus, proportion of Sm was positively associated with permanent grasslands characterized by high NDF, ADF and ADL values, low OMD and yield values and a high proportion of spe- 
Table 2 Mean, standard deviation (s.d.) and maximum (Max) values obtained for the most representative species (proportion of dry matter, as \%) of permanent grasslands sampled at two sampling periods: ensilage stage (SS) and hay stage (HS).

\begin{tabular}{|c|c|c|c|c|c|c|}
\hline \multirow[b]{2}{*}{ Species } & \multicolumn{3}{|c|}{ SS } & \multicolumn{3}{|c|}{ HS } \\
\hline & Mean & s.d. & Max & Mean & s.d. & $\operatorname{Max}$ \\
\hline \multicolumn{7}{|l|}{ Grasses } \\
\hline Agrostis capillaris & $8 \cdot 27$ & $9 \cdot 21$ & $39 \cdot 82$ & $12 \cdot 43$ & $12 \cdot 99$ & $60 \cdot 81$ \\
\hline Alopecurus pratensis & $3 \cdot 30$ & 8.91 & $49 \cdot 78$ & $2 \cdot 89$ & $7 \cdot 28$ & $35 \cdot 00$ \\
\hline Anthoxanthum odoratum & $1 \cdot 23$ & $3 \cdot 00$ & $21 \cdot 24$ & $0 \cdot 68$ & $1 \cdot 81$ & $13 \cdot 35$ \\
\hline Arrhenatherum elatius & $3 \cdot 88$ & 8.46 & $47 \cdot 14$ & $4 \cdot 98$ & 11.52 & $60 \cdot 82$ \\
\hline Bromus mollis & $3 \cdot 76$ & $8 \cdot 45$ & $47 \cdot 32$ & $1 \cdot 48$ & $4 \cdot 00$ & $31 \cdot 83$ \\
\hline Dactylis glomerata & $10 \cdot 49$ & $14 \cdot 41$ & $79 \cdot 52$ & $11 \cdot 84$ & $17 \cdot 63$ & $87 \cdot 75$ \\
\hline Elytrigia repens & 1.50 & $4 \cdot 70$ & $32 \cdot 81$ & $2 \cdot 14$ & $6 \cdot 38$ & $44 \cdot 98$ \\
\hline Festuca arundinacea & $0 \cdot 87$ & $4 \cdot 49$ & $35 \cdot 94$ & $1 \cdot 11$ & $5 \cdot 84$ & $41 \cdot 89$ \\
\hline Festuca pratensis & $1 \cdot 61$ & $6 \cdot 21$ & $48 \cdot 75$ & $2 \cdot 22$ & $8 \cdot 11$ & $56 \cdot 95$ \\
\hline Festuca rubra & $7 \cdot 31$ & $12 \cdot 50$ & $61 \cdot 02$ & $6 \cdot 15$ & $10 \cdot 85$ & $59 \cdot 90$ \\
\hline Holcus lanatus & $6 \cdot 25$ & $12 \cdot 16$ & $80 \cdot 98$ & $7 \cdot 02$ & $11 \cdot 89$ & $59 \cdot 39$ \\
\hline Lolium perenne & 6.53 & $10 \cdot 72$ & $57 \cdot 72$ & $5 \cdot 76$ & $10 \cdot 72$ & $69 \cdot 00$ \\
\hline Phleum pratense & $0 \cdot 89$ & $2 \cdot 61$ & $15 \cdot 62$ & $1 \cdot 61$ & $4 \cdot 50$ & $23 \cdot 46$ \\
\hline Poa pratensis & $4 \cdot 23$ & $5 \cdot 68$ & $41 \cdot 28$ & $4 \cdot 46$ & $5 \cdot 73$ & $32 \cdot 60$ \\
\hline Poa trivialis & $2 \cdot 98$ & $5 \cdot 89$ & $41 \cdot 08$ & $1 \cdot 85$ & $3 \cdot 32$ & $20 \cdot 03$ \\
\hline Trisetum flavecens & $3 \cdot 54$ & $0 \cdot 41$ & $5 \cdot 01$ & $4 \cdot 61$ & $6 \cdot 68$ & $37 \cdot 26$ \\
\hline \multicolumn{7}{|l|}{ Forbs } \\
\hline Cerastium spp. & $1 \cdot 60$ & $2 \cdot 34$ & $10 \cdot 83$ & $1 \cdot 20$ & $1 \cdot 82$ & 8.48 \\
\hline Gallium mollugo & 0.63 & $3 \cdot 30$ & $29 \cdot 63$ & 0.59 & $2 \cdot 52$ & $24 \cdot 62$ \\
\hline Heracleum sphondylium & 1.00 & $3 \cdot 82$ & $23 \cdot 77$ & 1.05 & $6 \cdot 02$ & $52 \cdot 49$ \\
\hline Plantago lanceolata & $1 \cdot 22$ & $3 \cdot 14$ & $22 \cdot 24$ & 0.56 & $1 \cdot 44$ & $8 \cdot 00$ \\
\hline Ranunculus acris & $1 \cdot 34$ & $3 \cdot 04$ & $22 \cdot 73$ & $0 \cdot 88$ & $2 \cdot 07$ & $11 \cdot 00$ \\
\hline Rumex acetosa & 0.54 & $2 \cdot 50$ & $22 \cdot 16$ & 0.33 & $1 \cdot 37$ & $10 \cdot 00$ \\
\hline Taraxacum officinale & $4 \cdot 42$ & $7 \cdot 39$ & $61 \cdot 08$ & 1.54 & $2 \cdot 81$ & $16 \cdot 36$ \\
\hline Urtica dioica & $0 \cdot 46$ & $4 \cdot 32$ & $52 \cdot 80$ & $0 \cdot 81$ & $5 \cdot 59$ & $49 \cdot 35$ \\
\hline \multicolumn{7}{|l|}{ Legumes } \\
\hline Lathyrus pratensis & 0.45 & 1.43 & $10 \cdot 98$ & $0 \cdot 37$ & $1 \cdot 24$ & $8 \cdot 49$ \\
\hline Trifolium pratense & 0.68 & $4 \cdot 68$ & $55 \cdot 80$ & $0 \cdot 61$ & $4 \cdot 04$ & $47 \cdot 00$ \\
\hline Trifolium repens & $1 \cdot 27$ & $2 \cdot 45$ & $15 \cdot 77$ & $1 \cdot 04$ & $2 \cdot 71$ & $21 \cdot 00$ \\
\hline Vicia sativa & $0 \cdot 42$ & $1 \cdot 80$ & $17 \cdot 06$ & $0 \cdot 61$ & $2 \cdot 29$ & $17 \cdot 00$ \\
\hline \multicolumn{7}{|l|}{ Other } \\
\hline Senescent material & $6 \cdot 12$ & $10 \cdot 80$ & $80 \cdot 91$ & $6 \cdot 11$ & $4 \cdot 97$ & $26 \cdot 11$ \\
\hline
\end{tabular}

Minimum values are 0.00 for all species, with the exception of senescent material at HS which presented a minimum value of $0.37 \%$. Twenty grasses, sixty-eight forbs, seven legumes and two monocotyledons not grasses are not listed.

cies such as Fe. rubra and Elytrigia repens. In contrast, permanent grasslands characterized by high proportions of L. perenne were associated with high estimated OMD, VI and yield values and low ADL and structural carbohydrate contents. Abundance of D. glomerata, Taraxacum officinale and Poa trivialis was positively correlated with abundance of L. perenne. High proportions of Alopecurus pratensis, Festuca pratensis, Ag. capillaris, Ho. lanatus, Fe. rubra and Bromus mollis were associated with low CP content, whereas high proportions of T. officinale, Urtica dioica, E. repens, Sm and Arrhenatherum elatius were correlated to high $\mathrm{CP}$ and ash content values.

\section{Intrastructure}

The intrastructure indicated the reproducibility of the compromise for each of the two sampling periods, making it possible to analyse how the species-forage parameters relationship differed between the two sampling periods. The projection of the forage parameter variables and the projection of the species on the compromise axes are shown in the trajectories factor map (Figure 3). The two periods were plotted on separate graphs to show (3a) projection of forage parameters in SS, (3b) projection of species proportions in SS, (3c) projection of forage parameters in HS and 
(a)
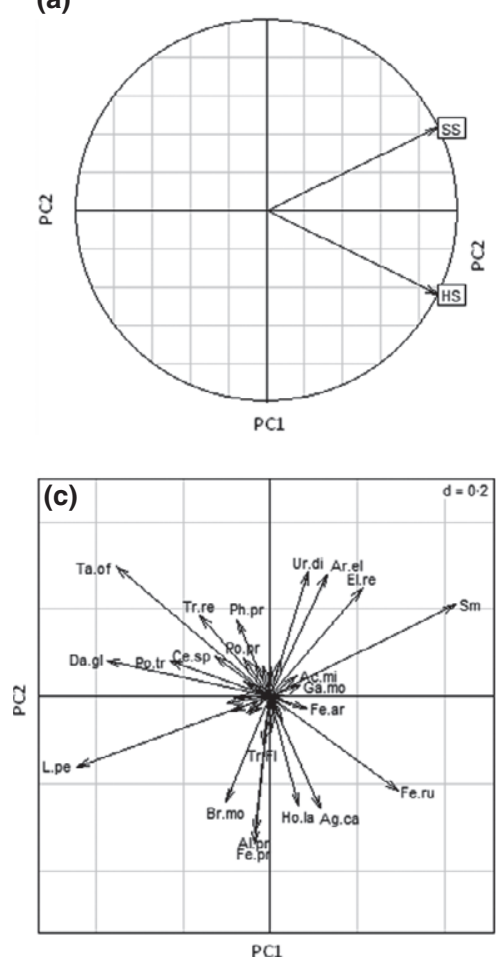

\section{2}

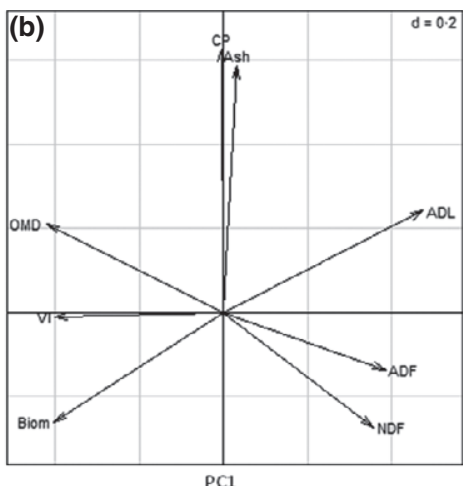

PC1 


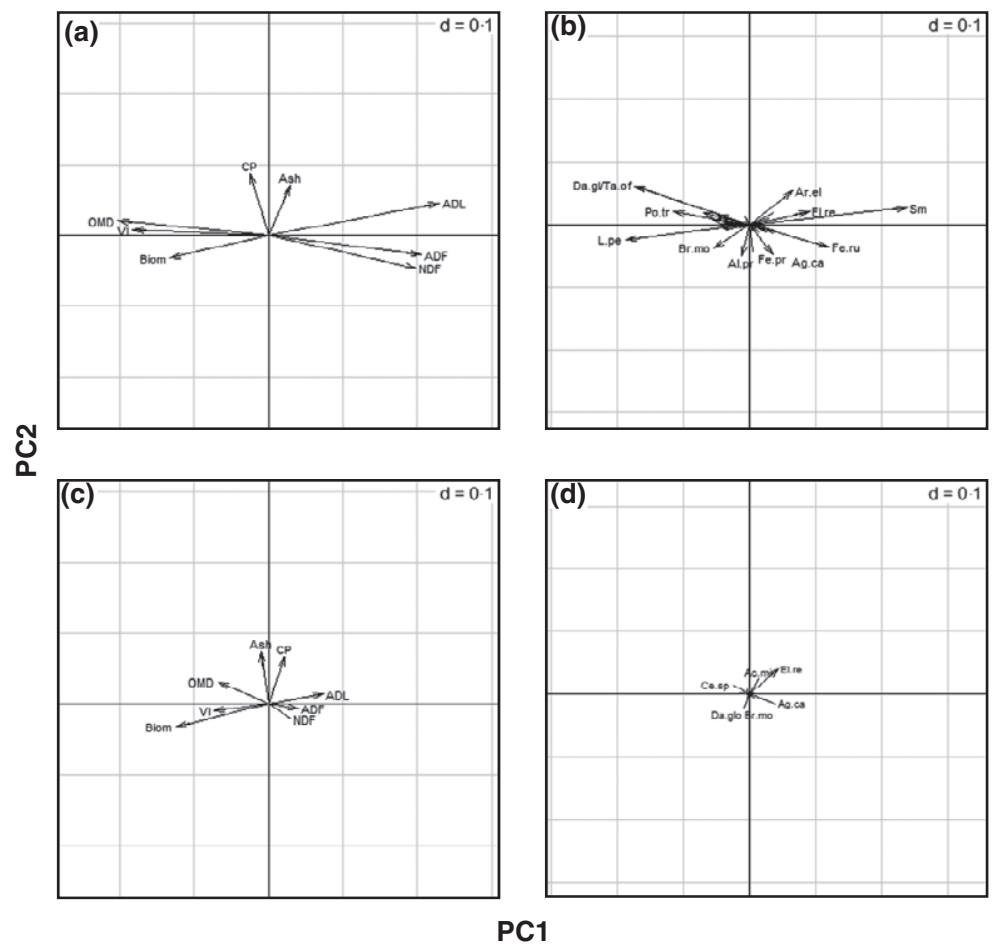

Figure 3 Trajectories factor map projection of the coordinates of the eight forage parameters and 125 species proportions on the principal component factor map of the compromise. $\mathrm{PCl}=$ first principal component. $\mathrm{PC} 2$ = second principal component. The two periods [Silage stage (SS) and Hay stage (HS)] have been plotted on separate graphs to show (a) projection of forage parameters in SS, (b) projection of species proportions in SS, (c) projection of forage parameters in HS, (d) projection of species proportions in HS. d values give grid size. Ag.ca, Agrostis capillaris; Br.mo, Bromus mollis; Ce.sp, Cerastium spp; El.re, Elytrigia repens; Da.gl, Dactylis glomerata; Fe.pr, Festuca pratensis; Fe.ru, Festuca rubra; Ar.el, Arrhenatherum elatius; Ac.mi, Achilea millefolium; Sm, Senescent material; Po.tr, Poa trivialis; Ta.of, Taraxacum officinale; L.pe, Lolium perenne; Al.pr, Alopecurus pratensis; Biom, yield; ADL, acid detergent lignin; ADF, acid detergent fibre; NDF, neutral detergent fibre; CP, crude protein; OMD, organic matter digestibility; VI, voluntary intake.

B. mollis, T. officinale and Ranunculus acris. Class $\times$ period interaction was significant $(P<0.01)$ for all forage parameters with the exception of yield and CP content, and for proportion of $T$. officinale and $\mathrm{Sm}$. On the factor map of the co-inertia analysis (Figure 4), classes 1 and 4 were opposed to classes 2 and 3 according to the first axis (i.e., gradient of forage quantity and quality), while classes 1 and 3 were opposed to classes 2 and 4 on the second axis (i.e., gradient of CP).

Class $1(n=28)$ was characterized by low yield and low feed value. Average values were 1.7 and $2.6 \mathrm{t} \mathrm{DM}$ per ha yield, 117 and $88 \mathrm{~g}$ DM CP, 0.66 and 0.61 OMD and 65.9 and $61.3 \mathrm{~g}$ per $\mathrm{kg} \mathrm{BW}^{0.75}$ VI for SS and HS respectively (Table 3 ). This class was chiefly characterized by abundant senescent material in SS (Sm 20\%) decreasing to $7 \%$ in HS and high proportions of Ar. elatius, Ho. lanatus, E. repens, Ag. capillaris,
Al. pratensis, $U$. dioica and Gallium mollugo in both sampling periods (Table 4).

Class $2(n=49)$ was characterized by high yield and high feed-value parameters (except CP). Average values were 4.51 and 5.98 t DM per ha yield, 108 and $81 \mathrm{~g} \mathrm{~kg} \mathrm{DM}^{-1} \mathrm{CP}, 0.72$ and $0.62 \mathrm{OMD}$ and 71.4 and $65.7 \mathrm{~g}$ per $\mathrm{kg} \mathrm{BW}^{0.75} \mathrm{VI}$ for SS and HS respectively (Table 3). The characteristic species of Class 2 were Ag. capillaris, L. perenne, D. glomerata, Fe. rubra, Ho. lanatus, Al. pratensis, T. officinale and Cerastium spp. (Table 4).

Class $3(n=48)$ was characterized by high yield and high feed-value parameters. Average values were 5.83 and $6.98 \mathrm{t}$ DM per ha yield, 121 and $86 \mathrm{~g} \mathrm{~kg}$ $\mathrm{DM}^{-1} \mathrm{CP}, 0.75$ and $0.64 \mathrm{OMD}, 73.3$ and $66.3 \mathrm{~g}$ per $\mathrm{kg}$ $\mathrm{BW}^{0.75}$ VI, and 535 and $600 \mathrm{~g}$ per $\mathrm{kg}$ NDF for SS and HS respectively (Table 3 ). The characteristic species of Class 3 were D. glomerata, T. officinale and L. perenne. 


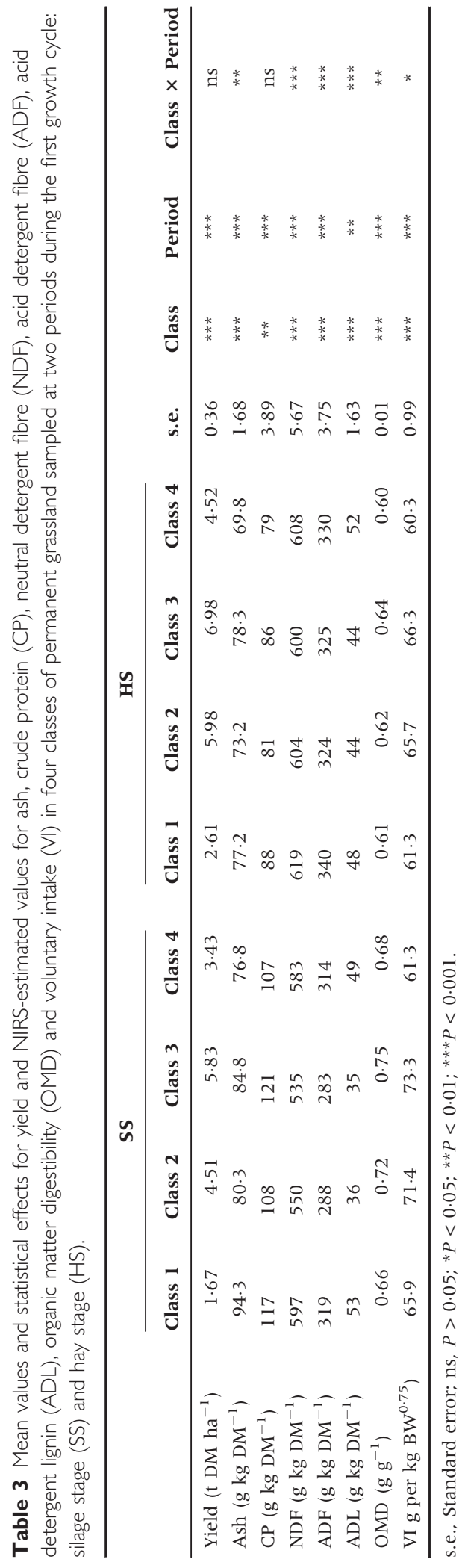

Taraxacum officinale decreased significantly between SS and HS (Table 4).

Class $4 \quad(n=28)$ was differentiated from other classes by low feed-value parameters, including low CP. Average values were 3.43 and $4.52 \mathrm{t} \mathrm{DM}$ per ha yield, 107 and $79 \mathrm{~g}$ per $\mathrm{kg}$ DM CP, 0.68 and 0.60 OMD, 61.3 and $60.3 \mathrm{~g}$ per $\mathrm{kg} \mathrm{BW} \mathrm{BW}^{0.75} \mathrm{VI}$, and 583 and $608 \mathrm{~g}$ per $\mathrm{kg}$ NDF for SS and HS respectively (Table 3). The characteristic species of Class 4 were Fe. rubra, Ag. capillaris, Ho. lanatus, G. mollugo and Sm (Table 4).

\section{Discussion}

\section{The correlation between forage parameters and botanical composition}

We found very broad variability in the chemical composition and feed value of the grassland-derived forages used in this study. The range of values in our dataset was similar to the range reported by Baumont et al. (2007) for green forages from the first growth cycle in French permanent grasslands. This large range in terms of both species identity and relative abundance reflects the diversity of plant communities sampled in this study.

An interesting finding of this study was the lack of correlation between $\mathrm{CP}$ and other feed-value parameters. Several studies have reported that CP and OMD decrease in a similar way with time (Andrieu et al., 1981; Andres et al., 2005). Our data did not confirm this pattern, even though both variables were well correlated $(r=0 \cdot 86)$ when the two sampling periods were combined, but this correlation almost disappeared when the CP-OMD linkage was investigated separately for each sampling period. Accordingly, for a given point in time, grassland forage can be characterized as either low OMD and high CP or low OMD and low-CP.

A surprising finding of this study was the positive correlation between Sm and CP content. The possible presence of fungal diseases of grasses on Sm could explain this result. According to Queiroz et al. (2012), plants characterized by moderate rust diseases showed lower CP content than disease-free plants whereas plants characterized by high rust infection showed higher CP content than disease-free plants. Potter (1987) also reported that the presence of crown rust increased the CP content of perennial and Italian ryegrasses. According to Dimmock and Gooding (2002), rust causes physical damage to plants thereby causing leaves to senesce prematurely through desiccation. This reduces translocation but greatly increases retention of amino acids which could increase the CP content of forage. 
Table 4 Mean values and statistical effects for proportion of different species in four classes of permanent grasslands sampled at two periods during the first growth cycle: ensilage stage (SS) and hay stage (HS).

\begin{tabular}{|c|c|c|c|c|c|c|c|c|c|c|c|}
\hline & \multicolumn{4}{|c|}{ SS } & \multicolumn{4}{|c|}{ HS } & \multirow[b]{2}{*}{ Class } & \multirow[b]{2}{*}{ Period } & \multirow[b]{2}{*}{$\begin{array}{l}\text { Class } \\
\times \text { period }\end{array}$} \\
\hline & $\begin{array}{c}\text { Class } \\
1\end{array}$ & $\begin{array}{c}\text { Class } \\
2\end{array}$ & $\begin{array}{c}\text { Class } \\
3\end{array}$ & $\begin{array}{c}\text { Class } \\
4\end{array}$ & $\begin{array}{c}\text { Class } \\
1\end{array}$ & $\begin{array}{c}\text { Class } \\
2\end{array}$ & $\begin{array}{c}\text { Class } \\
3\end{array}$ & $\begin{array}{c}\text { Class } \\
4\end{array}$ & & & \\
\hline Agrostis capillaris & $5 \cdot 47$ & $12 \cdot 78$ & $2 \cdot 99$ & $12 \cdot 23$ & $7 \cdot 54$ & $16 \cdot 71$ & $8 \cdot 43$ & $16 \cdot 66$ & $* * *$ & $* *$ & ns \\
\hline Bromus mollis & $1 \cdot 07$ & $5 \cdot 14$ & 5.90 & $0 \cdot 39$ & $0 \cdot 74$ & $1 \cdot 39$ & $2 \cdot 73$ & $0 \cdot 21$ & $* * *$ & $* *$ & ns \\
\hline Cerastium spp. & 0.71 & $2 \cdot 03$ & $2 \cdot 14$ & $0 \cdot 79$ & $1 \cdot 19$ & 1.54 & $1 \cdot 34$ & 0.35 & $* * *$ & ns & ns \\
\hline Elytrigia repens & $7 \cdot 18$ & 0.05 & 0.54 & 0.02 & $9 \cdot 82$ & $0 \cdot 04$ & 1.04 & 0.01 & $* * *$ & ns & ns \\
\hline Dactylis glomerata & $4 \cdot 61$ & $6 \cdot 31$ & 23.55 & $1 \cdot 30$ & 5.93 & $8 \cdot 32$ & $22 \cdot 56$ & $5 \cdot 50$ & $* * *$ & ns & ns \\
\hline Festuca pratensis & $0 \cdot 21$ & $1 \cdot 76$ & $2 \cdot 20$ & $1 \cdot 76$ & $2 \cdot 05$ & $2 \cdot 20$ & $2 \cdot 41$ & $2 \cdot 09$ & ns & ns & ns \\
\hline $\begin{array}{l}\text { Festuca } \\
\text { arundinacea }\end{array}$ & $3 \cdot 02$ & $0 \cdot 22$ & $0 \cdot 14$ & $1 \cdot 08$ & $4 \cdot 35$ & $0 \cdot 08$ & $0 \cdot 00$ & 1.56 & $* * *$ & ns & ns \\
\hline Festuca rubra & $1 \cdot 61$ & $6 \cdot 58$ & $0 \cdot 16$ & $26 \cdot 56$ & 0.90 & $6 \cdot 89$ & $0 \cdot 61$ & $19 \cdot 61$ & $* * *$ & ns & ns \\
\hline Phleum pratense & $0 \cdot 56$ & $0 \cdot 70$ & 1.46 & $0 \cdot 57$ & 0.55 & $1 \cdot 30$ & $2 \cdot 63$ & 1.47 & $* *$ & ns & ns \\
\hline $\begin{array}{l}\text { Anthoxanthum } \\
\text { odoratum }\end{array}$ & $0 \cdot 00$ & $2 \cdot 04$ & $1 \cdot 40$ & $0 \cdot 77$ & $0 \cdot 04$ & $1 \cdot 10$ & $0 \cdot 66$ & 0.59 & $* *$ & ns & ns \\
\hline $\begin{array}{l}\text { Arrhenatherum } \\
\text { elatius }\end{array}$ & $13 \cdot 55$ & 0.93 & $3 \cdot 15$ & $0 \cdot 60$ & $15 \cdot 94$ & $2 \cdot 27$ & $3 \cdot 89$ & $0 \cdot 65$ & $* *$ & ns & ns \\
\hline Gallium mollugo & 1.58 & $0 \cdot 19$ & $0 \cdot 03$ & 1.51 & $0 \cdot 17$ & $0 \cdot 37$ & $0 \cdot 00$ & $2 \cdot 38$ & $* * *$ & ns & ns \\
\hline Lathyrus pratensis & $0 \cdot 00$ & $0 \cdot 58$ & $0 \cdot 21$ & $1 \cdot 06$ & $0 \cdot 05$ & $0 \cdot 062$ & $0 \cdot 02$ & $0 \cdot 86$ & $* * *$ & ns & ns \\
\hline $\begin{array}{l}\text { Heracleum } \\
\text { sphondylium }\end{array}$ & $0 \cdot 00$ & 0.95 & $2 \cdot 21$ & $0 \cdot 00$ & $0 \cdot 00$ & $1 \cdot 24$ & $2 \cdot 07$ & $0 \cdot 00$ & $* *$ & ns & ns \\
\hline Holcus lanatus & $13 \cdot 85$ & $5 \cdot 75$ & $3 \cdot 45$ & $4 \cdot 34$ & $14 \cdot 04$ & $4 \cdot 44$ & $7 \cdot 19$ & $4 \cdot 19$ & $* * *$ & ns & ns \\
\hline Senescent material & $19 \cdot 94$ & $2 \cdot 12$ & $2 \cdot 00$ & $6 \cdot 36$ & $7 \cdot 39$ & $4 \cdot 92$ & $5 \cdot 49$ & $7 \cdot 99$ & $* * *$ & ns & $* * *$ \\
\hline Urtica dioica & $2 \cdot 13$ & $0 \cdot 08$ & $0 \cdot 15$ & $0 \cdot 00$ & $4 \cdot 31$ & $0 \cdot 06$ & $0 \cdot 00$ & $0 \cdot 00$ & $* * *$ & ns & ns \\
\hline Poa trivialis & $0 \cdot 92$ & $3 \cdot 04$ & $5 \cdot 75$ & $0 \cdot 17$ & $0 \cdot 82$ & $2 \cdot 04$ & $3 \cdot 17$ & $0 \cdot 31$ & $* * *$ & ns & ns \\
\hline Taraxacum officinale & $1 \cdot 19$ & $3 \cdot 41$ & $9 \cdot 84$ & $0 \cdot 13$ & $1 \cdot 00$ & 1.45 & $2 \cdot 76$ & $0 \cdot 18$ & $* * *$ & $* * *$ & $* * *$ \\
\hline Plantago lanceolata & $0 \cdot 32$ & $2 \cdot 47$ & $0 \cdot 54$ & $1 \cdot 09$ & $0 \cdot 04$ & $0 \cdot 98$ & $0 \cdot 17$ & $1 \cdot 00$ & $* * *$ & ns & ns \\
\hline Lolium perenne & $0 \cdot 69$ & $11 \cdot 63$ & $8 \cdot 36$ & $0 \cdot 32$ & $1 \cdot 82$ & $9 \cdot 45$ & $7 \cdot 33$ & $0 \cdot 50$ & $* * *$ & ns & ns \\
\hline Ranuculus acris & $0 \cdot 10$ & $1 \cdot 64$ & 1.91 & $1 \cdot 09$ & $0 \cdot 29$ & 1.53 & $0 \cdot 96$ & $0 \cdot 21$ & $* * *$ & $* * *$ & ns \\
\hline Rumex acetosa & $0 \cdot 00$ & $0 \cdot 84$ & $0 \cdot 82$ & $0 \cdot 06$ & $0 \cdot 00$ & 0.51 & 0.52 & $0 \cdot 04$ & $* *$ & ns & ns \\
\hline Trifolium repens & $0 \cdot 00$ & $1 \cdot 83$ & 1.91 & $0 \cdot 48$ & $0 \cdot 07$ & $1 \cdot 37$ & 1.71 & $0 \cdot 29$ & $* * *$ & ns & ns \\
\hline Alopecurus pratensis & $5 \cdot 75$ & $4 \cdot 44$ & $2 \cdot 52$ & $0 \cdot 19$ & $4 \cdot 01$ & $5 \cdot 23$ & 1.33 & 0.055 & $* * *$ & ns & ns \\
\hline
\end{tabular}

ns, $P>0.05 ; * * P<0.01 ; * * * P<0.001$.

Our results further confirmed the well-known negative correlation between structural carbohydratelignin contents and OMD, VI and yield. Several papers have reported similar relationships between ADF and ADL content and OMD (Demarquilly et al., 1995) and between cell-wall content and VI (Mertens, 1994) in forages.

Looking at the relationship between botanical composition and forage parameters, the first factor map of the compromise revealed a species gradient based on ability to compete using natural resources (nutrients, light etc.; Grime, 1977) associated with a feed-value gradient. Permanent grasslands rich in competitive grasses such as L. perenne and D. glomerata associated with high forage parameter values (Schubiger et al., 2001; Bruinenberg et al., 2002) were opposed to more conservative grasses such as Fe. rubra and Ag. capillaris associated with low forage parameter values (Frame, 1991; Pavlu et al., 2006; Pontes et al., 2007). The presence of these functional groups of species (Cruz et al., 2002) is generally associated with a gradient of several environmental variables (precipitation, relative irradiation, soil type, air temperature and nitrogen) (Ejrnaes and Bruun, 2000; Jeangros et al., 2000) and/or with different management history [fertilization, drainage (Hopkins, 1986) and intensity of management (Pavlu et al., 2006)].

Other major species playing an important role in this study were forbs. The feed value of some of these species is not yet sufficiently described in the literature. Forbs may contain secondary compounds which could modify - positively or negatively - the feed value of permanent grasslands. The few papers citing feed values for this functional group do not always 


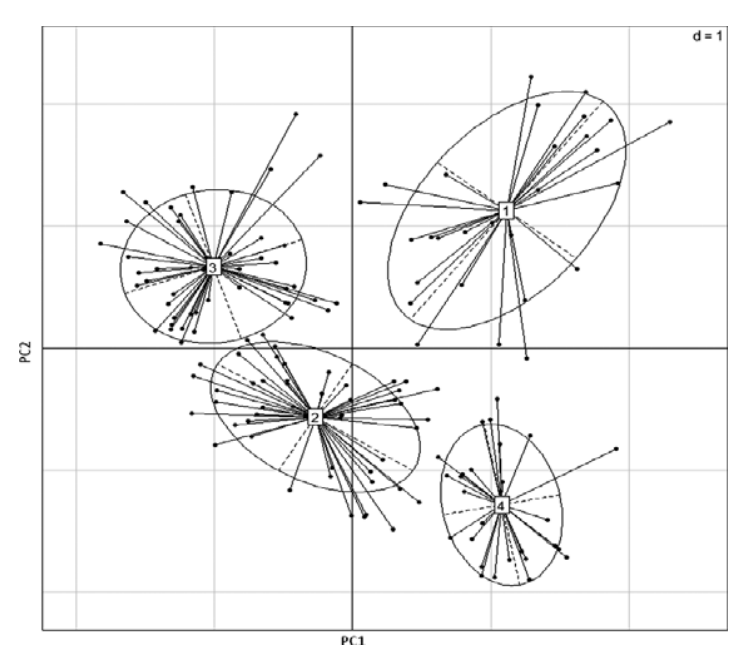

Figure 4 The four classes of permanent grassland charted in the two-dimensional space of the co-inertia analysis defined by principal component axes I and 2 . values give grid size. $\mathrm{PCl}=$ principal component $1 ; \quad \mathrm{PC} 2=$ principal $2 ; \mathrm{d}$ value gives grid size.

give consistent results. Schubiger et al. (2001), using the in vitro method of Tilley and Terry (1963), reported OMD values for T. officinale that were similar to ryegrass, whereas Wilman and Riley (1993) and Derrick et al. (1993), using in vivo digestibility, reported lower values than for ryegrass. Derrick et al. (1993) however, reported similar intake values between T. officinale and leafy ryegrass. In addition, Seither et al. (2012) found that the nutritive value of herbage from diverse grasslands was in some cases higher than grass-dominated swards, but Hofmann and Isselstein (2005) concluded that the introduction of forbs in a permanent grassland decreased forage digestibility. In our study, the presence of $T$. officinale was positively correlated with abundance of $L$. perenne and was associated with high OMD and VI values, as suggested by Tilley and Terry (1963). Other species associated with high-nutritive forage were Cerastium spp, Ra. acris and Heracleum sphondylium. However, the forbs that negatively correlated to high-nutritive forage included G. mollugo and $U$. dioica as reported by Hofmann and Isselstein (2005).

Another interesting finding was that the relationships between botanical composition and forage parameters remained stable during the period of the first growth cycle despite the fact that differences in nutritive value and yield of permanent grasslands were smaller in HS than in SS. This means that forage parameters for permanent grassland composed mainly of competitive species were higher than forage parameters for permanent grassland composed of conservative species during both SS and HS, despite the contrasting patterns of change in feed value of these groups. Duru et al. (2008) and Andueza et al. (2010) have already shown that permanent grasslands composed of species that employ resource-capture strategies (competitive species), such as L. perenne and D. glomerata, had higher digestibility values at the beginning of the cycle but also showed a stronger decline than permanent grasslands composed of species that employ resource-conservation strategies, such as Fe. rubra and Ag. capillaris. Similarly, Andueza et al. (2013) found the same pattern for VI on two different permanent grasslands. In this study, we showed similar patterns, but the novelties are as follows: first, that the grasslands dominated by competitive species preserve their higher forage quality (OMD and VI) compared to grasslands dominated by conservative species despite the sharp decline observed between SS and HS for OMD; secondly, that the trends identified using our database can be generalized to a large range of permanent grasslands.

\section{Characterization of permanent grasslands}

The permanent grasslands selected and analysed in this study can be categorized into four plant community classes that provide different forage qualities. The co-analysis of botanical composition and forage parameters underlined the association between permanent grasslands with high proportions of competitive species such as D. glomerata, L. perenne, T. officinale and Cerastium spp. with high yield and feed values (classes 2 and 3), especially when they are cut or grazed early (as shown by the comparison at SS vs. HS). On the other hand, permanent grasslands composed mainly of Fe. rubra, Ag. capillaris, Ar. elatius and Ho. lanatus with high proportions of Sm were associated with high fibre contents and low feed values (classes 1 and 4), particularly in the early stages of the growth cycle (SS). Our analysis also showed that grassland types can be further discriminated according to their forage $\mathrm{CP}$ and ash contents, allowing us to separate Class 1 from 4 and Class 2 from Class 3. This study thus demonstrates that each class can be characterized by a given species assemblage. However, several species can be found in different classes and in significant proportions (e.g. Ag. capillaris in Class 2 and Class 4 or L. perenne in Class 2 and Class 3). This result underlines that grassland class cannot be determined by a single characteristic species but rather by the co-occurrence of a set of characteristic species. Permanent grasslands dominated by Ag. capillaris and Fe. rubra (Class 4) are thus characterized by low feed value, whereas permanent grasslands dominated by L. perenne and Ag. capillaris (Class 2) showed high feed value. Forbs can also be indicative species despite their lower proportions in 
the classes. T. araxacum officinale, Cerastium spp. and He. sphondylium were found in high feed-value classes whereas G. mollugo and $U$. dioica belonged to low feedvalue classes. Consequently, an important result of this study was that we were able to identify several indicator species or species associations characterizing the yield and feed value of permanent grasslands: D. glomerata and T. officinale for grasslands with high yield potential and high nutritive value, Ag. capillaris and $L$. perenne for grasslands with similar characteristics but low CP content, Fe. rubra and Ag. capillaris for permanent grasslands with low yield and low feedvalue parameters, and the association of high proportions of Sm with species such as E. repens, Ho. lanatus or Ar. elatius indicated permanent grasslands with low yield, OMD and intake values but high CP content. This typology differs from that proposed by Daccord et al. (2006), who also linked nutritive value to botanical composition of permanent grasslands. However, the typology proposed by Daccord et al. (2006) was mainly based on the proportions of different families in the grasslands, although they did take into account the proportion of certain individual species like ryegrass.

Senescent material was found to be associated with permanent grasslands of Class 1 . This can be explained by the fact that Class-1 pastures were associated with more extensive management (data not shown) than the other more intensively managed grassland classes, which would equate to a higher quantity of rejections at the end of autumn especially in the SS. The difference of Sm between SS and HS in this class is a result that can be explained by the increase in green forage between SS and HS periods in relation to Sm.

An outcome of this study is the proposed permanent grasslands typology scheme using forage quality and yield based on a set of common grassland species including grasses and forbs. This typology, based on assemblages of species easily identified in permanent grasslands, can be used without deep knowledge of botany. We anticipate these results to be complementary to other tools available, such as the functional classification of permanent grasslands according to grass growth strategies (Cruz et al., 2002). Practical use of this permanent grasslands classification by farmers and land managers (earlier use of grasslands composed of competitive species and then later use of permanent grasslands composed of conservative species) would allow more sustainable and efficient farm-scale management of permanent grasslands.

\section{Conclusions}

Applying STATICO - an original statistical method mainly used in ecological science - enabled us to iden- tify the relationships between botanical composition and forage parameters (yield and forage quality) of permanent grasslands at two important maturity stages of the first growth cycle. We established relationships between the dominant species and forage quality parameters of permanent grasslands in a large range of samples and proved that these correlations remain stable over the first growth cycle. This study highlights links between the abundance of certain species in permanent grasslands and their forage quality. We identified a set of indicator species or species associations that characterized the yield and forage quality of permanent grasslands. These findings offer a useful tool for more sustainable and efficient management of permanent grasslands that can also be used in addition to other functional typology tools that farmers already use in practice.

\section{Acknowledgements}

The authors thank the staff at experimental stations 1354 UE RT and 1296 UEMA, the agricultural extension services (EDE63 and CA63) and the farmers that participated in this study. A.M. Rodrigues received a 'CAPES' Fellowship from the Brazilian Government.

\section{References}

Andres S., Giraldez F.J., Lopez S., Mantecon A.R. and Calleja A. (2005) Nutritive evaluation of herbage from permanent meadows by near-infrared reflectance spectroscopy: 1. Prediction of chemical composition and in vitro digestibility. Journal of the Science of Food and Agriculture, 85, 1564-1571.

Andrieu J., Demarquilly C. and Wegat-Litre E. (1981) Tables de prévision de la valeur alimentaire des fourrages. In: Demarquilly C. (ed.) Prévision de la valeur nutritive des aliments des ruminants, pp. 345-577. Versailles, France: INRA Publications.

Andueza D., Cruz P., Farruggia A., Baumont R., Picard F. and Michalet-Doreau B. (2010) Nutritive value of two meadows and relationships with some vegetative traits. Grass and Forage Science, 65, 325-334.

Andueza D., Picard F., Jestin M., Andrieu J. and B A UMONT R. (2011) NIRS prediction of the feed value of temperate forages: efficacy of four calibration strategies. Animal, 5, 1002-1013.

Andueza D., Picard F., Jestin M. and Aufrere J. (2013) The effect of feeding animals ad libitum vs. at maintenance level on the in vivo digestibility of mown herbage from two permanent grasslands of different botanical composition. Grass and Forage Science, 68 , $418-426$.

Baumont R., Dulphy J.P., Sauvant D., Tran G., Meschy F., Aufrere J Peyraud J.L. and Champciaux P. (2007) Les tables de la valeur des aliments. In: Alimentation des bovins, ovins et caprins. 
Besoins des animaux-Valeurs des aliments, pp. 181-275. Quae, Versailles, France.

Bruinenberg M.H., Valk H., Korevaar H. and Struik P.C. (2002) Factors affecting digestibility of temperate forages from seminatural grasslands: a review. Grass and Forage Science, 57, 292-301.

Cattell R.B. (1966) The scree test for the number of factors. Multivariate Behavioral Research, 1, 245-276.

Cruz P., Duru M., Therond O., Theau J.P., Ducourtieux C., Jouany C., Al Haj Khaled R. and ANSQUER P. (2002) Une nouvelle approche pour caractériser les prairies naturelles et leur valeur d'usage. Fourrages, 172, 335-354.

Daccord R., Wyss U., Kessler J., Arrigo Y., Rouel M., Lehmann J. and Jeangros B. (2006) Estimation de la valeur $d u$ fourrage des prairies. Lausanne, Switzerland: Agridea.

Demarquilly C., Chenost M. and Giger S. (1995) Pertes fécales et digestibilité des aliments et des rations. In: Jarrige R., Ruckebusch Y., Demarquilly C., Farce M.H. and Journet M. (eds) Nutrition des ruminants domestiques. Ingestion et digestion, pp. 601-647. Paris, France: INRA editions.

Derrick R.W., Moseley G. and Wilman D. (1993) Intake, by sheep, and digestibility of chickweed, dandelion, dock, ribwort and spurrey, compared with perennial ryegrass. Journal of Agricultural Science Cambridge, 120, 51-61.

Dimmock J.P.R.E. and Gooding M.J. (2002) The influence of foliar diseases, and their control by fungicides, on the protein concentration in wheat grain: a review. Journal of Agricultural Science Cambridge, 138, 349-366.

Doledec S. and Chessel D. (1994) Co-inertia analysis: an alternative method for studying species-environment relationships. Freshwater Biology, 31, 277-294.

Dray S., Chessel D. and Thioulouse J. (2003) Coinertia analysis and the linking of ecological tables. Ecology, 84, 3078-3089.

Duru M., Cruz P., Al Haj Khaled R., Ducoutieux C. and Theau J.P. (2008) Relevance of plant functional types based on leaf dry-matter content for assessing digestibility of native grass species and species-rich grassland communities in spring. Agronomy Journal, 100, 1622-1630.

EjRnAes R. and BRuUn H.H. (2000) Gradient analysis of dry grassland vegetation in Denmark. Journal of Vegetation Science, 11, 573-584.

FAO (2008) Statistical Database. http://faostat.fao.org/

FRAME J. (1991) Herbage production and quality of a range of secondary grass species at five rates of fertilizer nitrogen application. Grass and Forage Science, 46, 139-151.

GRIME J.P. (1977) Evidence for the three primary strategies in plants and its relevance to ecological and evolutionary theory. American Naturalist, 111, 1169 1194.

Hofmann M. and Isselstein J. (2005) Species enrichment in an agriculturally improved grassland and its effects on botanical composition, yield and forage quality. Grass and Forage Science, 60, 136-145.
Hopkins A. (1986) Botanical composition of permanent grassland in England and Wales in relation to soil, environment and management factors. Grass and Forage Science, 41, 237-246.

Hulin S., Carrere P., Chabalier C., Farruggia A., Landrieaux J., Orth D., Piquet M., Riviere J. and SEYTRE L. (2011) Diagnostic prairial en zones fromagères AOP du Massif central. OUTIL 1 : Typologie multifonctionnelle des prairies. Aurillac, France : Pôle fromager AOP Massif central.

Jeangros B., Scehovic J., Troxler J. and Bosset J.O. (2000) La composition de l'herbe des paturages de montagne est-elle différente de celle des prairies de plaine ? Revue Suisse d'Agriculture, 32, 63-68.

Legendre P. and Gallagher E.D. (2001) Ecologically meaningful transformations for ordination of species data. Oecologia, 129, 271-280.

Martin B., Verdier-Metz I., Buchin S., Hurtaud C. and Coulon J.B. (2005) How do the nature of forages and pasture diversity influence the sensory quality of dairy livestock products? Animal Science, 81 , 205-212.

MERTEns D.R. (1994) Regulation of forage intake. In: Fahey G.C., Collins M., Mertens D.R. and Moser L.E. (eds) Forage Quality, Evaluation and Utilization, pp. 450-532. Madison, WI, USA: American Society of Agronomy, Inc., Crop Science Society of America, Inc., Soil Science Society of America, Inc.

Pavlu V., Hejcman M., Pavlu L., Gaisler J. and Nezerkova P. (2006) Effects of continuous grazing on forage quality, quantity and animal performance. Agriculture, Ecosystems and Environment, 113, 349-355.

Pelve M.E., Olsson I., Spörndly E. and Eriksson T. (2012) In vivo and in vitro digestibility, nitrogen balance and methane production in non-lactating cows and heifers fed forage harvested from heterogeneous semi-natural pastures. Livestock Science, 144, 48-56.

Pontes L., Carrere P., Andueza D., Louault F. and Soussana J.F. (2007) Seasonal productivity and nutritive value of temperate grasses found in seminatural pastures in Europe. Responses to cutting frequency and N supply. Grass and Forage Science, 62, 485-496.

Potter L.M. (1987) Effect of crown rust on regrowth, competitive ability and nutritional quality of perennial and Italian ryegrass. Plant Pathology, 36, 455-461.

Queiroz O.C.M., Kim S.C. and Adesogan A.T. (2012) Effect of treatment with a mixture of bacteria and fibrolytic enzymes on the quality and safety of corn silage infested with different levels of rust. Journal of Dairy Science, 95, 5285-5291.

Reheul D., De Vliegher A., Bommele L. and Carlier L. (2007) The comparison between temporary and permanent grassland. In: De Vliegher A. and Carlier L. (eds) Permanent and Temporary Grassland: Plant, Environment and Economy. Grassland Science in Europe, 12, pp. 1-13. Belgian Society for Grassland and Forage Crops: Merlbeke, Belgium.

Rosignol N., Andueza D., Carrere P., Cruz P., Duru M., Fiorelli J.L., Michaud A., Plantureux 
S., Pottier E. and Baumont R. (2014) Assessing population maturity of three perennial grass species: influence of phenology and tiller demography along latitudinal and altitudinal gradients. Grass and Forage Science, 69, 534-548.

S A S (2000) User's Guide, Statistics, Version, 8th edn. Cary, NC: SAS Inst., Inc..

Schubiger F.X., Lehmann J., Daccord R., Arrigo Y., JeAngros B. and Scehovic J. (2001) Valeur nutritive des plantes des prairies. 5. Digestibilité de la matière organique. Revue Suisse d'Agriculture, 33, 354-359.

Seither M., Wrage N. and Isselstein J. (2012) Sward composition and grazer species effects on nutritive value and herbage accumulation. Agronomy Journal, 104, 488-506.

Simier M., Blanc L., Pellegrin F. and Nandris D. (1999) Approche simultannée de K couples de tableaux: application à l'étude des relations pathologie végétaleenvironnement. Revue de Statistique Appliquée, 47, 31-46.

Sokal R.R. and Rohlf F.J. (1981). Biometry, 2nd edn. New York, USA: W.H. Freeman \& Cie.

TH i o L OUSE J. (2011) Simultaneous analysis of a sequence of paired ecological tables: a comparison of several methods. The Annals of Applied Statistics, 5, 2300-2325.

Thioulouse J. and Chessel D. (1987) Les analyses multitableaux en écologie factorielle I. De la typologie d'état à la typologie de fonctionnement par l'analyse triadique. Acta Oecologica Oecologia Generalis, 8, 463480.

Thioulouse J., Chessel D., Doledec S. and Olivier J.M. (1997) ADE-4: a multivariate analysis and graphical display software. Statistics and Computing, 7, 75-83.
Thioulouse J., Simier M. and Chessel D. (2004) Simultaneous analysis of a sequence of paired ecological tables. Ecology, 85, 272-283.

Tilley M. and Terry R. (1963) A two-stage technique for the in vitro digestion of forage crops. Journal of British Grassland Society, 18, 104-111.

Todorova P.A. and Kirilov A.P. (2002) Changes in the permanent grassland composition and feeding value during the growing season. In: Durand J.L., Emile J.C., Huygue C. and Lemaire G. (eds) Multi-Function Grasslands. Quality Forages, Animal Products and Landscapes. Grassland Science in Europe, 7, pp. 179 180. Association Française pour la Production Fourragère. Versailles, France.

Tutin T.G., Heywood V.H., Burges N.A., Valentine D.H., Walters S.M. and Webi D.A. (1964-1980) Flora Europea, vols 1-5. Cambridge, UK: Cambridge University Press.

Van Soest P.J. and Robertson J.B. (1980) Systems of analysis for evaluating fibrous feeds. In: Pidgen W.J., Balch C.C. and Graham M. (eds) IDRC No 134, pp. 4960. Ottawa, Canada: International Development Research Centre.

Van Soest P.J., Robertson J.B. and Lewis B.A. (1991) Methods for dietary fiber, neutral detergent fiber, and nonstarch polysaccharides in relation to animal nutrition. Journal of Dairy Science, 74, 3583-3597.

Wilman D. and Riley J.A. (1993) Potential nutritive value of a wide range of grassland species. Journal of Agricultural Science Cambridge, 120, 43-49. 